\title{
THE SOUL OF ANIME
}





\section{THE SOUL OF ANIME}

Collaborative Creativity and

Japan's Media Success Story

IAN CONDRY

Duke University Press

Durham and London 2013 
(C) 2013 Duke University Press

All rights reserved

Printed in the United States of America

on acid-free paper $@$

Designed by Jennifer Hill

Typeset in Garamond Premier Pro

by Keystone Typesetting, Inc.

Library of Congress Cataloging-in-

Publication Data appear on the last

printed page of this book.

This work is licensed under the Creative Commons Attribution-NonCommercial-NoDerivs 3.0 Unported License. To view a copy of this license, visit http:// creativecommons.org/licenses/by-nc-nd/3.0/ or send a letter to Creative Commons, 444 Castro Street, Suite 900, Mountain View, California, 9404I, USA. "Noncommercial" as defined in this license specifically excludes any sale of this work or any portion thereof for money, even if the sale does not result in a profit by the seller or if the sale is by a $50 \mathrm{I}(\mathrm{c})(3)$ nonprofit or NGO. 
For Nick, Jackson, and Alec 
